Scientia studia, São Paulo, v. 11, n. 4, p. 811-39, 2013

\title{
तิ \\ As posições de Newton, Locke e Berkeley sobre a natureza da gravitação
}

\author{
Silvio Seno Ghibeni
}

\begin{abstract}
@
RESUMO

Ao defender, nos Princípios matemáticos de filosofia natural, a existência de uma força de gravitação universal, Newton desencadeou uma onda de dúvidas e objeções filosóficas. Suas próprias declarações sobre a natureza da gravitação não são facilmente interpretáveis como formando um conjunto consistente de opiniões. Por um lado, logo após fornecer as três definições de "quantidades de forças centrípetas" (Defs. 6-8), Newton observa que está tratando tais forças “matematicamente”, sem se pronunciar sobre sua realidade física. Mas, por outro lado, no Escólio Geral inserido no final da segunda edição do livro, Newton diz que foi capaz de "explicar" vários fenômenos de movimento por meio da força de gravidadeque ele mostrou ser um tipo de força centrípeta -, embora não tivesse ainda conseguido explicar a causa dessa força. Uma interpretação plausível dessas últimas afirmações é que Newton acreditava que pôde inferir, a partir dos fenômenos, a existência da força de gravidade, enquanto agente causal real de certos movimentos, mas que ainda não havia tido sucesso em descobrir a causa dessa causa. O objetivo principal do presente artigo não é aprofundar a análise histórica das declarações de Newton, mas examinar como essa questão se insere no debate mais geral sobre o estatuto epistemológico das hipóteses científicas que transcendem a experiência imediata. Segundo a posição defendida, entre muitos outros, por John Locke, tais hipóteses devem ser interpretadas como tentativas legítimas de descrever aspectos inobserváveis da realidade. Em contraste com isso, no caso específico das hipóteses sobre forças - de gravitação ou quaisquer outras -, George Berkeley argumentou vigorosamente a favor de sua interpretação como meros artifícios teóricos úteis às "demonstrações matemáticas" na ciência da mecânica. Ao longo da análise das vantagens e desvantagens filosóficas dessas posições opostas, indica-se aqui que, embora a interpretação realista pareça fazer mais justiça ao desenvolvimento real da física após os Princípios matemáticos, a interpretação instrumentalista de Berkeley tem o mérito filosófico inegável de representar uma adesão mais firme ao empirismo, que é, de um modo ou de outro, valorizado por ambas as partes envolvidas na disputa sobre a natureza da gravitação.
\end{abstract}

PALAVRAS- GhaVe • Força de gravidade. Newton. Locke. Berkeley. Realismo científico. Instrumentalismo.

\section{INTRODUÇÃO}

Ao defender, nos Princípios matemáticos de filosofia natural (Philosophiae naturalis principia mathematica), em 1687, a existência de uma força de gravitação universal, Newton inaugurou uma era nova e extraordinariamente produtiva no estudo científico dos fe- 
nômenos de movimento, mas ao custo de gerar uma onda de dúvidas e objeções filosóficas. A razão básica para isso é que essa força não podia ser inserida no referencial metafísico e metodológico da filosofia natural da época. Esse referencial é o mecanicismo, que havia alcançado uma forma bastante refinada nos Princípios da filosofia (Principia philosophiae) de Descartes (1971 [1644]). Na concepção mecanicista de mundo, toda ação física de um corpo sobre outro deve dar-se por contato, enquanto que a força proposta por Newton parecia ser uma força de atração a distância, ou seja, capaz de atuar sobre corpos distantes sem a intermediação de outros que pudessem formar uma cadeia causal de corpos em contato.

Para entender esse aparente conflito, é preciso retroceder um pouco na análise, e lembrar por que, afinal de contas, a nova mecânica desembocou, nas mãos de Newton, na postulação de uma força desse tipo. Não darei aqui detalhes do argumento, bastante técnico, oferecido por Newton no livro 3 dos Princípios matemáticos, nem tampouco da versão semi-popular oferecida por Roger Cotes, em seu famoso prefácio da segunda edição dessa obra, de 1713. Limito-me a apontar que a necessidade dessa força decorria, de forma fundamental, da nova concepção da natureza do movimento que se estabeleceu a partir de Galileo, Descartes e do próprio Newton. Nessa concepção, em contraste com a concepção aristotélica, o movimento que constituía um estado e que, portanto, não requer nenhuma causa, é o movimento retilíneo uniforme. Assim, por exemplo, a queda de uma pedra nas proximidades da superfície da Terra requer uma causa, já que é um movimento retilíneo, porém acelerado, como estabeleceu Galileo de forma quantitativa precisa. Igualmente, os movimentos da Lua ao redor da Terra, ou dos planetas ao redor do Sol, também requerem causas, já que são movimentos curvilíneos e, portanto, acelerados. Na teoria mecanicista desenvolvida por Descartes, tais causas são, necessariamente, o contato com outros corpos. Ora, como nesses casos não vemos outros corpos empurrando a pedra ou os planetas, Descartes viu-se na contingência de postular, a título explícito de hipótese, a existência de corpos invisíveis, constituindo certos fluidos que girariam em turbilhões ao redor da Terra, do Sol e dos outros planetas.

O que Newton aproveitou e o que rejeitou dessa proposta teórica? Aproveitou, é claro, a visão inercial do movimento, segundo a qual, nesses exemplos, a queda da pedra e os movimentos do sistema solar dar-se-iam pela ação de causas eficientes. Foi, porém, além de Descartes ao propor que tais causas são forças, ou, mais precisamente, “forças impressas". Isso abre, em princípio, uma possibilidade de generalização da proposta cartesiana. Também permitiu a quantificação da relação causa e efeito, mediante, primeiro, a introdução dos conceitos de quantidade de matéria (ou massa) e de quantidade de movimento (massa vezes velocidade); e, segundo, pelo segundo axioma do movimento, que estipula ser a força impressa proporcional à mudança da quantida- 
de de movimento. Foram esses os ingredientes teóricos para o referido argumento do livro 3, que, em uma genial comparação quantitativa do movimento acelerado da pedra com o da Lua, levou à conclusão de que as forças em ambos os casos obedecem a uma mesma fórmula: a força é proporcional ao produto das massas e inversamente proporcional à distância que separa os corpos. A partir disso, Newton concluiu, por ulterior generalização, que havia uma força de gravitação universal. Em outras palavras, o fenômeno conhecido desde a Antiguidade como "gravidade" - a tendência para baixo dos corpos ditos "graves" - caracterizaria também, mutatis mutandis, os corpos celestes e quaisquer outros corpos do universo.

Tudo isso pode ser visto como uma extensão da proposta cartesiana. Mas tal proposta continha elementos que foram cabalmente repudiados por Newton. Primeiro, no plano metodológico Newton não aceitava - ao menos não sem maiores qualificações, como veremos adiante - o método de hipóteses, tal como aqui empregado por Descartes. Depois, rejeitou, por razões físicas diversas e poderosas, a hipótese específica dos turbilhões de matéria sutil. Com isso, Newton comprou dois problemas interligados, com os quais se veria às voltas até o fim de sua vida, a saber, (1) explicar qual, exatamente, o seu método para a filosofia natural, esclarecendo, em particular, se admitia ou não o uso de hipóteses; e (2) explicar fisicamente a força de atração gravitacional. Seus escritos - os dois livros principais, em suas várias edições e rascunhos, seus artigos, suas anotações marginais, sua correspondência - apresentam ao historiador interessado na elucidação filosófica desses pontos um desafio dos mais complexos de que se tem notícia na história da filosofia da ciência. Não pretendo aqui adentrar essa selva de textos, adensada pela vasta literatura secundária, surgida especialmente nas últimas cinco décadas. Preciso, porém, mencionar brevemente algumas das passagens mais salientes, para ilustrar as dificuldades e preparar o terreno para o restante deste estudo.

\section{As passagens Relevantes de Newton}

Começando pelos Princípios matemáticos, o primeiro comentário de Newton relevante ao presente artigo aparece logo após as definições daquilo que Newton chama de "quantidades" das forças centrípetas (Defs. 6 a 8). (Notemos, de antemão, que a força de gravitação universal é uma força centrípeta.) Expressando-se com deliberada vagueza sobre a natureza física de tais forças, que fazem que um corpo "tenda para o centro" do movimento, Newton justifica-se dizendo que pretende, nesse ponto, "apenas dar uma noção matemática de tais forças, sem considerar suas causas e sedes físicas" (Principia, p. 5). E, um pouco adiante: 
eu uso os termos atração, impulso e propensão de qualquer espécie na direção de um centro, promiscuamente e indiferentemente, um no lugar do outro, considerando aquelas forças não fisicamente, mas matematicamente. Logo, o leitor não deve imaginar que por tais palavras eu de algum modo tome para mim a tarefa de definir o tipo, ou modo de ação, das causas ou razões físicas [de tal propensão], ou que atribua forças, em um sentido verdadeiro e físico, a certos centros (que são apenas pontos matemáticos), sempre que eu fale de centros como atraindo, ou dotados de poderes atrativos (Principia, p. 5-6).

Essa é uma posição que dá margem a duas interpretações, ambas igualmente claras e que vão numa mesma direção filosófica. A primeira, mais moderada - adotada por Samuel Clarke, o mais famoso defensor da filosofia natural de Newton em sua época -, é a de que Newton aqui simplesmente está buscando quantificar o estudo do movimento, porém se distanciando da questão metafísica de suas causas. Ao rotular certas dessas causas de "forças centrípetas" ou, depois, de "forças de atração gravitacional”, estaria simplesmente enfeixando certos fenômenos em determinadas classes, e permitindo que fossem corretamente calculados matematicamente, sem se pronunciar sobre aquilo que, metafisicamente, determinaria sua ocorrência. A segunda interpretação avança mais, e sustenta que essa determinação nem mesmo é possível, ao menos não no escopo da filosofia natural, e que, portanto, toda referência a forças deve ser entendida de forma meramente instrumental. Forças seriam ficções úteis à matematização do estudo do movimento. Essa a posição defendida por George Berkeley, que examinarei na seção 3 .

Tudo estaria bem se Newton não houvesse se pronunciado, tanto nos Principios matemáticos como em vários outros lugares, em sentido aparentemente contrário a essas interpretações, especialmente a segunda delas. ${ }^{\mathbf{1}}$ Tais pronunciamentos podem ser classificados em três tipos. Primeiro, há as inúmeras frases em que, ao longo do texto, Newton fala de forças como se fossem reais, ou seja, como determinantes reais dos movimentos. Depois, há suas declarações no sentido de que "inferiu" ou "deduziu" a existência de forças a partir dos fenômenos e de que, com elas, pôde explicar esses movimentos. Finalmente, há suas diversas tentativas de formular hipóteses capazes de

1 As dificuldades de interpretar os textos de Newton de modo que formem um conjunto consistente têm sido, desde o início, fonte de perplexidade entre os comentadores. Algumas referências úteis e que conduzem à vasta literatura hoje existente sobre o tema são Cohen, 1966; Dijksterhuis, 1986; Shapiro, 2004; McDonald, 1972; Janiak, 2007; Barra, 1995; Clatterbaugh, 1999 e diversos dos artigos reunidos em Cohen \& Smith, 2002. Em Barra (2010) defende-se, mediante sofisticada argumentação, a tese de que ao dizer, nas passagens acima transcritas e em outras semelhantes, que estaria tratando as forças "matematicamente", Newton não as estaria tornando ontologicamente vazias, como usualmente se assume na literatura e como continuarei assumindo no restante deste trabalho. 
explicar fisicamente a força de gravidade, algumas delas expressas em cartas, e ao menos uma publicada, como uma das questões (queries) da Óptica (Opticks) de 1704.

Vejamos breves amostras desses três tipos de pronunciamentos que aproximam Newton de uma posição realista quanto à existência de forças e, em particular, da força de gravitação.

As frases que, ao menos em uma interpretação literal, indicam uma posição realista quanto a forças são abundantes nos Princípios matemáticos (para nos limitarmos a essa obra). ${ }^{2}$ A própria definição de força impressa é uma delas. "Uma força impressa é uma ação exercida sobre um corpo, de modo a mudar seu estado de repouso ou de movimento uniforme ao longo de uma linha reta" (Def. 4). Essa definição é seguida pelo comentário: "Essa força consiste apenas na ação, e não permanece no corpo quando a ação cessa". Nem a definição nem o comentário parecem fazer sentido numa interpretação puramente "matemática", instrumentalista da noção de força. Observações semelhantes aplicam-se à definição de força centrípeta (Def. 5) e aos comentários que a seguem. Depois, a formulação dos dois primeiros axiomas de movimento também é feita numa linguagem em que forças são consideradas os agentes causais reais das mudanças de movimento. Saltando agora, para não me alongar nesse caso, para a famosa proposição 5 do livro 3, ela diz "que os planetas circunjovianos gravitam na direção de Júpiter, os circunsaturnais na direção de Saturno, os circunsolares na do Sol; e que, pela força de suas gravidades, são desviados de seus movimentos retilíneos, e retidos em órbitas circulares". No escólio dessa proposição Newton diz o seguinte:

A força que retém os corpos celestes em suas órbitas foi, até aqui, chamada de força centrípeta. Porém, estando claro agora que não pode ser outra senão uma força de gravitação, chamá-la-emos doravante de gravidade. Pois a causa daquela força centrípeta que retém a Lua em sua órbita se estenderá para todos os planetas, pelas Regras 1, 2 e 4. (Principia, p. 4,10).

Mais uma vez, essa importante identificação de Newton da força de gravidade com a força que retém os corpos celestes em suas órbitas não parece esgotar-se na mera identificação de suas fórmulas matemáticas. Lembremos, a esse respeito, que as regras 1 e 2 a que Newton se refere aqui são justamente regras sobre causas naturais, em um sentido físico robusto. Regra 1, "não se devem admitir mais causas para as coisas naturais do que as que sejam verdadeiras e suficientes para explicar as aparências."

2 Para uma útil análise de vários casos de referência realista a forças na Óptica - e em particular na "questão 31" -, cf. Cala Vitery, 2006. O autor propõe que o sucesso alcançado por Newton com a teoria da força gravitacional foi o fator determinante para que formulasse hipóteses sobre a existência de outras forças, que não a gravitacional, para explicar fenômenos químicos, luminosos, térmicos, magnéticos etc. 
Regra 2, "portanto, aos mesmos efeitos naturais devemos, tanto quanto possível, atribuir as mesmas causas".

Passando agora às declarações explícitas de Newton, de que "deduziu" a existência de forças a partir dos fenômenos, restrinjamo-nos mais uma vez aos Princípios matemáticos, indo direto para o famoso escólio geral, que Newton acrescentou em sua segunda edição. O parágrafo que mais nos interessa é o penúltimo, em que Newton observa, inicialmente, que "até aqui explicamos os fenômenos dos céus e de nosso mar pelo poder da gravidade”. Ora, a noção clássica de explicação, que certamente foi assumida por Newton (mesmo porque ainda não haviam surgido alternativas), consiste na identificação de uma causa real do fato a ser explicado. Embora Newton continue a frase dizendo que "ainda não assinalamos a causa desse poder", isso não implica que o poder de atração gravitacional não exista, antes o contrário. $\mathrm{O}$ "ainda” indica que Newton concebia a investigação da causa da gravidade como uma etapa ulterior da pesquisa, cujo balizamento ele faz no mesmo parágrafo.

Isto é certo: esse poder [de atração] tem de provir de uma causa que penetre até os próprios centros do Sol e dos planetas, sem sofrer a menor diminuição de sua força; e ele opera não segundo a quantidade das superfícies das partículas em que age (como as causas mecânicas faziam), mas segundo a quantidade de matéria sólida [massa] que contém, e propaga sua virtude para todos os lados, até distâncias imensas, decrescendo sempre na razão inversa dos quadrados das distâncias (Principia, p. 456).

A interpretação realista da força de gravidade está clara nessa passagem, bem como, de modo ainda mais explícito, no comentário sobre o método da "filosofia experimental", que vem logo em seguida.

Nessa filosofia, proposições particulares são inferidas dos fenômenos e, depois, tornadas gerais por indução. Foi assim que a impenetrabilidade, a mobilidade, a força impulsiva dos corpos e as leis do movimento e da gravitação foram descobertas. E para nós basta que a gravidade realmente exista, e aja de acordo com as leis que explicamos, servindo abundantemente para dar conta de todos os movimentos dos corpos celestes e de nosso mar (Principia, p. 457).

A observação que Newton faz, de que a explicação da força de gravidade não pode ser buscada dentro do referencial mecanicista estrito, em que as forças são todas forças de contato, constitui o fulcro de um grave problema, o problema a que aludi no primeiro parágrafo deste artigo. Mas a força de gravidade era um elemento central de- 
mais na mecânica newtoniana para ser deixado sem explicação. Armou-se, assim, um dilema para Newton. Ou bem ele abdicava dessa tarefa, mediante a adoção de uma atitude agnóstica, ou mesmo instrumentalista - atitudes essas bastante estranhas ao espírito da época - ou bem enfrentava o desafio de propor uma explicação não-mecânica para a gravidade. Ora, como estamos tentando mostrar, em que pesem as declarações com que abrimos as citações desta seção, Newton não embarca, ao menos não plenamente, na primeira rota. Mas também se recusou explicitamente a propor explicações para a força gravitacional nos Princípios matemáticos, obra em que o problema foi levantado. Diante disso, seus críticos, entre os quais se destacam Huygens e Leibniz, logo o acusaram de deixar a gravitação como um processo inexplicável de ação a distância, que se assemelharia às abominadas "forças ocultas" da filosofia escolástica. $\mathrm{Na}$ verdade, essa possibilidade era repugnante também ao próprio Newton, como se sabe por sua correspondência. ${ }^{3}$

Essa discussão conduz a outro grande tópico dos estudos sobre a filosofia natural de Newton, a saber, a sua atitude frente ao método de hipóteses. Já observei na seção introdutória deste trabalho que há aqui um ponto de conflito entre Descartes e Newton. A face mais clara desse conflito é a cabal rejeição que Newton faz das hipóteses cartesianas para explicar os fenômenos que Newton atribui à gravidade. Mas Newton faz também movimentos inequívocos no sentido de indicar a rejeição do próprio método de hipóteses. Essas indicações encontram-se espalhadas em seus escritos, desde textos anteriores aos Princípios matemáticos, como, principalmente, de forma cada vez mais pronunciada, após o lançamento de sua primeira edição, em 1687. Nela, o livro 3 continha uma lista de "hipóteses" de conteúdo variado. Mas na segunda edição, de 17¹3, elas foram renomeadas como "regras de raciocínio em filosofia" ou como "fenômenos" (cf. Cohen, 1966). Adicionalmente, fez inserir o escólio geral, em que, no parágrafo que estamos comentando, faz as famosas e polêmicas observações.

\footnotetext{
3 Em cartas a Richard Bentley, do início dos anos 1690, Newton rejeitou em termos enfáticos a inclusão da força de atração gravitacional entre as propriedades primárias dos corpos, que não necessitariam ser explicadas, sua pseudoexplicação pelo apelo a uma misteriosa ação a distância. Vejamos esses trechos de duas dessas cartas. "Você por vezes fala da gravidade como essencial e inerente à matéria. Por favor, não atribua a mim essa noção (...). É inconcebível que a matéria inanimada bruta possa, sem a mediação de alguma outra coisa que não seja material, operar sobre e afetar outra matéria sem contato mútuo, como teria de ser se a gravitação, no sentido de Epicuro, fosse essencial e inerente a ela. (...) Que a gravidade seja inata, inerente e essencial à matéria, de modo que um corpo possa agir a distância sobre outro através do vácuo, sem a mediação de alguma outra coisa, pela qual sua ação e força possam ser transportadas para o outro, é para mim absurdo tão grande, que creio que nenhum homem que tenha em assuntos filosóficos uma faculdade competente de pensar possa jamais nele incorrer. A gravidade há de ser causada por um agente que aja de forma constante, segundo certas leis; mas decidir se tal agente é material ou imaterial é algo que deixei para a consideração de meus leitores" (Newton apud Cajori, 1934, p. 633-4).
} 
Até aqui não fui capaz de descobrir, a partir dos fenômenos, a causa dessas propriedades da gravidade, e sobre isso eu não invento hipóteses [hipotheses non fingo]. Pois o que quer que não seja deduzido dos fenômenos deve ser chamado de hipótese; e hipóteses, quer metafísicas, quer físicas, quer sobre qualidades ocultas, quer mecânicas, não têm lugar na filosofia experimental (Principia, p. 457; segue-se então o trecho da última citação, acima).

Como se sabe, tanto a recusa em formular hipóteses para explicar a gravidade como a rejeição geral de hipóteses explicativas na filosofia natural foram violadas pelo próprio Newton. Em sua correspondência encontramos tentativas no sentido de explicar a gravidade apelando a hipóteses acerca da existência de certos fluidos que permeariam os corpos (não agindo, portanto, somente em suas superfícies, como não poderia ser), e até mesmo em um texto publicado, o Óptica, uma dessas tentativas é exposta ao público. Sintomaticamente, porém, essa hipótese não aparece no texto principal, mas como uma das questões que vêm no final do livro.4 As questões incluem, ademais, hipóteses diversas para explicar fenômenos ópticos, todas referindo-se a fluidos invisíveis.

Não está no escopo deste artigo a análise dessas curiosas hipóteses de Newton, nem as tensões que sua formulação introduz no seu pensamento em filosofia natural. Há uma literatura vasta sobre isso (cf. as referências dadas na nota 1). Meu propósito é mais limitado; ao notar que efetivamente Newton inventou hipóteses para explicar a força de gravidade, fica enfatizada, pela terceira vez, a sua adesão à interpretação realista dessa força, pois se ele a entendesse como mero artifício matemático, não se empenharia em explicá-la fisicamente. Além disso, o exame, a ser feito nas seções seguintes, das posições de Locke e Berkeley a esse respeito exigiria que alguma coisa sobre a posição do próprio Newton fosse dita como preparo do terreno. Passo, pois, ao caso de Locke.

4. "Não é esse meio muito mais rarefeito dentro dos corpos densos do Sol, estrelas, planetas e cometas do que nos espaços celestiais vazios que existe entre eles? E, passando-se daí para distâncias maiores, não vai ele ficando mais e mais denso, perpetuamente, causando desse modo a gravidade desses grandes corpos uns na direção dos outros, e de suas partes na direção dos corpos; cada corpo tentando ir das partes mais densas do meio para as mais rarefeitas?" (Óptica, questão 21) Nota-se que essa explicação parece assimilar a força gravitacional a uma espécie de empuxo. Mas o empuxo depende do volume, e não da massa, restando portanto a Newton acomodar essa crucial diferença - algo que, aparentemente, não fez. 
As posições de Newton, Logke e Berkeley sobre a natureza da gravitação

\section{A posiçÃo DE LoGKe}

Embora, em contraste com Descartes e Newton, Locke não tenha feito contribuições originais à filosofia natural, suas análises epistemológicas sobre o conhecimento nessa área foram de considerável importância. Ele acompanhou e participou diretamente das principais discussões travadas entre os filósofos naturais do seu tempo, muitos dos quais seus amigos pessoais, tendo mesmo sido eleito membro da Royal Society em 1688. Para nossos propósitos aqui, o que mais interessa é ver, ainda que de forma breve, sua posição quanto ao mecanicismo, a gravitação newtoniana e o uso de hipóteses na filosofia natural.

No Ensaio sobre o entendimento humano (An essayconcerning human understanding), Locke adota o que chama de "método histórico, direto" (Ensaio, 1, 1, 2), que propõe a limitação de qualquer investigação ao nível fenomenológico, ou, ao menos, a priorização epistêmica desse nível, relativamente a quaisquer elementos teóricos. Apesar disso, ele permitiu-se fazer, no oitavo capítulo do livro 2, uma "pequena excursão na filosofia natural" $(1975,2,8,22)$, justamente para tratar do mecanicismo ou, mais particularmente, de um de seus aspectos centrais, a saber, a distinção entre qualidades primárias e qualidades secundárias. Por sua concisão e clareza, esse texto de Locke tornou-se uma referência importante sobre o assunto. Nele, Locke faz a exposição e defesa do mecanicismo em sua versão mais pura, em que toda ação entre corpos tem de ser por contato, ou "impulso, o único modo pelo qual podemos conceber que os corpos operem" (1975, 2, 8, 11; Chibeni, no prelo). No livro 4, ao usar a distinção entre qualidades primárias e secundárias em um determinado passo de sua análise epistemológica, observa que essa distinção é parte de uma grande hipótese (ou teoria), a "hipótese corpuscular", e que a adotou por ser aquela "que se julga ser a que vai mais longe na direção de uma explicação inteligível das qualidades dos corpos" (1975, 4, 3, 16).

Essa caracterização, bastante apropriada, do estatuto epistemológico do mecanicismo - como sendo uma "hipótese" -, assim como o fato de Locke ter tomado cuidado para que virtualmente nenhum resultado positivo de sua teoria epistemológica dependesse dele, 5 não impediram que, ao considerar a questão da gravitação newtoniana, não se mostrasse disposto a abandonar ou flexibilizar a hipótese, postura que o conduziu a uma tese surpreendente, como veremos. Antes, porém, é preciso fazer algumas considerações preliminares.

Notemos, inicialmente, que Locke tece, no capítulo inicial de um texto pouco conhecido, Elementos de filosofia natural (Elements of natural philosophy), vários comentários sobre a gravitação que não deixam dúvida de que ele conhecia bem o argumento 
do terceiro livro dos Princípios matemáticos, e de que, seguindo Newton, adotou a interpretação realista da força de atração gravitacional. A questão da explicação dessa força não é abordada. Ele o faz, porém, em sua correspondência e em um livro cujo assunto principal é outro, Alguns pensamentos concernentes à educação (Some thoughts concerning education). Vejamos algumas passagens, começando com a correspondência com Edward Stillingfleet, o Bispo de Worcester. Como se sabe, nessa correspondência um dos temas centrais é a questão espinhosa, suscitada por Locke no Ensaio, da possibilidade de certos sistemas de matéria receberem, por um ato divino, a capacidade de pensar, bem como outros poderes mentais. As observações de Locke sobre a gravitação são feitas justamente ao longo da análise dessa questão. Na segunda resposta de Locke encontramos os seguintes trechos:

Pois se for uma regra correta de raciocínio negar que uma coisa exista, porque não podemos conceber como vem a ocorrer, quero que os que a usam adiram a ela e vejam que trabalho fará tanto na teologia como na filosofia; e se podem acrescentar mais alguma coisa a favor do ceticismo.

Para ficar dentro do presente assunto, do poder de pensar e do automovimento, atribuídos pelo Poder onipotente a algumas porções de matéria, a objeção a que isso ocorra é: não posso conceber como a matéria pense. Qual é a consequência [da regra em questão]? Ergo, Deus não pode lhe dar um poder de pensar. Que isso passe por uma razão boa, e então avancemos para outros casos pela mesma [regra]. Você não pode conceber como a matéria possa atrair matéria a uma distância qualquer, e muito menos à distância de 1000000 de milhas; ergo, Deus não lhe pode dar tal poder. Você não pode conceber como a matéria sinta e se mova por si mesma, ou afete um ser imaterial, ou por ele seja movida; ergo, Deus não lhe pode dar esses poderes; o que será, efetivamente, negar a gravidade e a revolução dos planetas ao redor do Sol; tornar os animais meras máquinas, sem capacidade de sentir e de se movimentar espontaneamente; e não conceder ao homem nem o sentido nem o movimento voluntário (...).

Se for perguntado por que eles [os críticos de Locke] limitam a onipotência de Deus relativamente a uma e não à outra dessas substâncias [matéria e espírito], tudo o que se poderá dizer é que não podem conceber como a substância sólida jamais possa mover-se a si própria. Tampouco podem, digo, conceber como uma substância criada não sólida mova-se a si própria. Mas pode haver algo desconhecido em uma substância imaterial, dizem; concordo, e o mesmo vale para uma substância material. Por exemplo, a gravitação da matéria na direção da matéria, observável em várias proporções, mostra inevitavelmente que há algo na matéria que não compreendemos, a menos que concebamos o auto-movimento na matéria, ou uma 
As posições de Newton, Logke e Berkeley sobre a natureza da gravitação

inexplicável e inconcebível atração na matéria, operando a distâncias imensas e quase incompreensíveis. Deve-se, pois, confessar que existe algo nas substâncias sólidas, e também nas não-sólidas, que não compreendemos. Isso, porém, sabemos: que ambas podem ter seus seres distintos, sem nenhuma atividade superadicionada a elas, a menos que você queira negar que Deus possa retirar de qualquer ser seu poder de agir - o que provavelmente se julgará ser algo muito presunçoso para alguém fazer. E, digo, é tão difícil conceber auto-movimento em uma substância criada imaterial, como material, como quer que você a considere. Portanto, isso não é razão para negar que a Onipotência possa dar um poder de auto-movimento a uma substância material, se bem o quiser, assim como a uma substância imaterial, visto que nenhuma delas pode ter tal poder por si mesma, e não concebemos como ele possa residir em qualquer uma delas (Segunda resposta, p. 4,63-5; grifos meus).

A posição de Locke parece ser, portanto, que embora não concebamos como a gravidade possa operar a distância, não podemos negar que Deus pode fazer com que opere desse modo, "superadicionando" à matéria esse poder. E mais; sabemos que ele de fato o fez, visto que a existência de tal poder se patenteia por seus efeitos. Essa é a interpretação proposta por Margaret Wilson (1979). Michael Ayers (1981, 1991) prefere entender Locke nessas passagens como simplesmente enfatizando o seu ceticismo quanto às causas da gravitação. É instrutivo, quanto a esse debate, ver mais um trecho da mesma carta, em que Locke indica a necessidade de retificar a já citada afirmação do oitavo capítulo do quarto livro do Ensaio, sobre o modo de ação dos corpos.

Considero que o que eu disse acima seja uma resposta completa a tudo o que o senhor possa inferir a partir de minha ideia de matéria, de liberdade, de identidade e do poder de abstrair. O senhor pergunta: “como pode (minha) posição sobre a liberdade conciliar-se com a ideia de que os corpos operam apenas por movimento e impulso?" Resposta: pela onipotência de Deus, que pode fazer com que todas as coisas que não envolvem contradição concordem entre si. É verdade que eu disse que "os corpos operam por impulso, e por nenhum outro modo" $[$ Ensaio, $4,8,11]$. De fato pensava assim quando o escrevi, e continuo não podendo conceber como possam operar de outra forma. Desde então, porém, fui convencido pelo incomparável livro do judicioso Sr. Newton de que constitui presunção demasiadamente ousada querer limitar o poder de Deus, quanto a isso, a partir de minhas estreitas concepções. A gravitação da matéria na direção da matéria, mediante processos inconcebiveis por mim, é não apenas uma demonstração de que Deus pode, se o quiser, atribuir aos corpos poderes e modos de operação que estejam 
acima daquilo que sejamos capazes de derivar de nossa ideia de corpo, ou que se possa explicar por aquilo que conhecemos da matéria, mas é também um exemplo inquestionável e patente em toda parte de que Ele de fato o fez. Portanto, na próxima edição de meu livro, tomarei o cuidado de retificar aquela passagem (Segunda resposta, p. 468; grifos meus).

Vemos, assim, em comparação com a frase do Ensaio citada anteriormente, que, sob a influência de Newton, Locke veio a admitir que os corpos podem operar, e de fato operam, de alguma forma que não seja por impulso, por ação a distância, embora não possamos conceber como isso se faz. Essa forma de ver as coisas parece mostrar que as interpretações de Wilson e Ayers não são totalmente incompatíveis entre si, ambas propondo que Locke reconheceu as limitações do corpuscularismo para acomodar a gravitação, bem como nossas limitações cognitivas para conceber qualquer outra explicação.

Vejamos agora a passagem de Alguns pensamentos concernentes à educação, em que o assunto vem à baila a propósito da recomendação de Locke de que, na educação, a teologia preceda a filosofia natural, pois, caso contrário, os alunos poderiam formar a concepção falsa de que no âmbito desta última tudo pode ser explicado.

(...) é evidente que pela mera matéria e movimento nenhum dos grandes fenômenos da natureza pode ser resolvido: um dos exemplos seria o [fenômeno] da gravidade, que penso ser impossível explicar por uma operação natural da matéria, ou qualquer outra lei de movimento, sem que a vontade positiva de um Ser Superior ordene que ocorra (Pensamentos, p. 184). ${ }^{\mathbf{6}}$

Tentando uma síntese, poderíamos dizer que, nessa posição madura, Locke mantém o corpuscularismo como o referencial dentro do qual a nossa capacidade de conceber o mundo se limita, mas que esse referencial não pode ser tomado como a descrição final do modo como o mundo de fato é. Essa conclusão está, notemos, inteiramente alinhada com outras posições defendidas por Locke no Ensaio, em que um ceticismo moderado está presente.

\footnotetext{
6 É interessante ver como o trecho continua, pela formulação de uma hipótese para explicar o dilúvio bíblico, hipótese essa que também consiste em postular algo que foge ao curso ordinário da natureza: "Logo, uma vez que o dilúvio não pode ser adequadamente explicado sem que se admita algo fora do curso ordinário da natureza, proponho que se considere que Deus tenha alterado o centro de gravidade da Terra por algum tempo (o que é tão inteligível quanto a própria gravidade, que talvez seja produzida por uma pequena variação de causas por nós desconhecidas), como um meio mais fácil de dar conta do dilúvio de Noé, do que qualquer das hipóteses já usadas para explicá-lo (...). Mas este não é o lugar para [discutir] esse argumento, aqui mencionado apenas de passagem, para ilustrar a necessidade de se recorrer, na explicação da natureza, a alguma coisa que esteja além da mera matéria e seu movimento" (Pensamentos, p. 184,-5).
} 
Para concluir, é interessante examinar brevemente a posição de Locke sobre o papel das hipóteses na filosofia em geral, e particularmente na filosofia natural.7 No capítulo 16 do livro 4 do Ensaio sobre os graus do assentimento, Locke observa que o domínio das proposições que são apenas prováveis divide-se naquelas sobre "questões de fato, que, caindo sob a observação, são capazes de serem testemunhadas pelos homens; [e naquelas] sobre coisas que, escapando à descoberta de nossos sentidos, não são capazes de tal testemunho" (Locke, 1975, 4, 16, 5). O primeiro caso engloba as leis científicas fenomenológicas; o segundo, as leis científicas introduzidas a título de hipóteses, e não a título de generalizações indutivas, como poderia ser o caso das primeiras. No capítulo 12 do mesmo livro 4, há um interessante parágrafo sobre "o verdadeiro uso de hipóteses". Após haver alertado, no parágrafo anterior, que "devemos tomar cuidado com hipóteses e princípios errados", ele diz:

Não que não possamos, para explicar os fenômenos da natureza, fazer uso de nenhuma hipótese provável qualquer que seja; hipóteses, se forem bem feitas, são pelo menos grandes auxiliares da memória e frequentemente direcionam-nos para novas descobertas. O que quero dizer, porém, é que não devemos adotar qualquer uma com demasiada pressa (...), antes que tenhamos examinado muito bem os detalhes, feito vários experimentos com a coisa que queremos explicar com nossa hipótese, e verificado que ela concorda com todos eles; que os nossos princípios [isto é, hipóteses] nos hajam conduzido bem ao longo desses experimentos, e que não sejam inconsistentes com um fenômeno natural quando parecem acomodar e explicar outro. E que pelo menos tomemos cuidado para que o nome princípios não nos engane, nem se imponha sobre nós, fazendo-nos aceitar por uma verdade inquestionável o que na realidade é, quando muito, uma conjetura muito duvidosa, como é o caso da maioria das (e quase diria de todas as) hipóteses da filosofia natural (Locke, 1975, 4, 12, 13).

Assim, Locke adverte contra a atribuição de um grau epistêmico demasiadamente elevado às hipóteses, ressalta sua função heurística, põe como condições de sua aceitação a sujeição a testes e a sua abrangência, destacando, por fim, a natureza irremediavelmente conjetural das hipóteses da filosofia natural. Não podemos deixar de notar a semelhança dessas observações com certas teses que os filósofos da ciência costumam esposar em nossos dias.

7 Cf., para uma análise mais detalhada desses pontos, Farr, 1987 e Chibeni, 2005. Defesas pioneiras da opinião segundo a qual Locke considerava legítimo o uso do método de hipóteses na filosofia natural foram feitas por Mandelbaum, 1964, Laudan, 1967 e Tipton, 1977. Para a opinião contrária, tradicional, Yost Junior, 1951 e Yolton, 1970. 
Outras posições, também muito atuais sobre o uso e avaliação de hipóteses na filosofia natural, são defendidas por Locke em um pequeno ensaio intitulado "Método", datado de 1694, transcrito integralmente e comentado por James Farr (1987). Nesse manuscrito, Locke propõe certa dose de tolerância para as falhas que as hipóteses evidenciem nas etapas iniciais de seu desenvolvimento. Também propõe que as hipóteses devem ser avaliadas em confronto com hipóteses alternativas, e não apenas com a experiência. Por fim, sugere que as hipóteses devem ser examinadas dentro de sistemas teóricos mais amplos, e não isoladamente, como se nota neste trecho singular:

Mas para mostrar qual dos lados tem a melhor pretensão à verdade e à adesão de seguidores, os dois sistemas completos [de hipóteses] devem ser comparados e considerados de forma integral, para que se veja qual é o mais consistente em todas as suas partes, qual é o menos obstruído por incoerências ou absurdos, e qual o mais isento de princípios emprestados e noções ininteligíveis. Este o meio mais correto de buscar a verdade e o mais seguro de não nos enganar de que lado ela está (Método, p. ₹¹).

Fazendo uma comparação geral das posições de Locke com as de Newton, quanto aos tópicos que estamos investigando neste trabalho, notamos, primeiro, a concordância plena de ambos quanto à incapacidade de conceber ações entre os corpos que não estejam dentro do quadro mecanicista estrito. Depois, enquanto Newton se referiu, em uma etapa bem delimitada da exposição de sua teoria, à interpretação "matemática" da força gravitacional - interpretação que, em princípio, abre caminho para posições antirrealistas -, Locke nunca se inclinou nessa direção, aparentemente nem mesmo havendo aventado tal possibilidade. Sua adesão a uma interpretação realista da força de gravidade é, portanto, firme e livre das hesitações encontradas em Newton. Quanto à espinhosa questão de sua explicação, vimos que Locke francamente advoga que não há recursos no domínio da filosofia natural para fornecê-la, cabendo a nós admitir que Deus atribuiu esse poder aos corpos, de uma forma que escapa totalmente à nossa compreensão. Newton, de sua parte, embora talvez pudesse admitir uma causa transcendente para a gravitação, empenhou-se ativamente em buscar uma causa material, por mais difícil que fosse. Uma última diferença diz respeito ao fato de que Locke adota, como vimos, uma posição realista geral sobre hipóteses, desde que satisfaçam a uma série de requisitos teóricos - requisitos esses que guardam relações de semelhança ou mesmo identidade com os que têm sido propostos por filósofos da ciência realistas científicos em nossos dias. Isso contrasta com a declarada e crescente antipatia de Newton a hipóteses em geral, em que pese a formulação - em termos cada vez mais comedidos, ao longo de sua carreira-de uma série de hipóteses científicas e filosóficas. 
As posições de Newton, Logke e Berkeley sobre a natureza da gravitação

Passemos agora ao caso de Berkeley, filósofo que, como veremos, embora tenha, como Locke, tomado Newton como referência, deslocou-se em uma direção oposta à de Locke, no que tange a vários desses pontos importantes da filosofia natural, da epistemologia e da metodologia científica.

\section{A gontribuição de Berkeley}

As contribuições originais e importantes de Berkeley para as discussões sobre o estatuto epistemológico das teorias científicas - e, em particular, para a questão da gravitação newtoniana - ficam muitas vezes eclipsadas pela atenção que se dá a sua tese da inexistência da matéria, que pode parecer estranha a quem não a conheça bem, e sugerir que Berkeley, com ela, teria se distanciado das discussões no âmbito da filosofia natural. ${ }^{8}$ A mera inspeção dos subtítulos de duas de suas obras mais famosas, Tratado sobre os princípios do conhecimento humano (A treatise concerning the principles of human knowledge), de 1710, e Três diálogos entre Hylas e Filônos (Three dialogues between Hylas and Philonous), de 1713, basta para retificar esse engano, pois neles Berkeley indica que entre seus objetivos principais está identificar "as principais causas de erro e dificuldades nas ciências", e propor uma nova interpretação filosófica que as torne "mais fáceis, úteis e resumidas". A consecução desses objetivos depende, fundamentalmente, da adesão de Berkeley ao empirismo em sua versão mais pura, segundo o qual "nada além de ideias é perceptível" (Comentários, $§ 5^{\circ}$ ). A partir dessa perspectiva, Berkeley defende uma tese que cumpre função central em sua análise da filosofia natural: a inatividade dos corpos, ou a inexistência de causas eficientes no mundo físico. Sendo os corpos meras coleções de ideias, e as ideias sendo inteiramente transparentes à nossa cognição - pois seu ser é ser percebido - a ausência, em nossa experiência, dessas coleções de ideias, de qualquer ideia de poder ativo, implica que não há poderes ativos nos corpos; ou seja, os corpos de fato não agem uns sobre os outros. Toda ação causal real é de natureza espiritual, de modo que os únicos seres dotados de poder causal são Deus e os espíritos criados. Tendo examinado detalhadamente esse assunto em outro lugar

80 imaterialismo berkeleyano não implica a irrealidade do mundo físico, como ele mesmo não se cansou de salientar. Mesas e cadeiras, planetas e estrelas têm, para Berkeley, existência tão real e objetiva quanto o homem comum ou o filósofo realista não berkeleyano supõem. O que muda é a base metafísica de sua existência, não sua existência mesma. Além disso, o acesso epistêmico a esses objetos é, para Berkeley, tão trivial quanto assume o homem comum, que crê percebê-los diretamente pelos sentidos. Essa proposta berkeleyana foi destinada para contrapor-se ao realismo representacionalista de seus principais antecessores, incluindo-se aí não somente os empiristas, como Locke, mas também os da escola cartesiana. Berkeley via nesse representacionalismo - segundo o qual o conhecimento do mundo exterior seria mediado pelas ideias - a armadilha que aprisionou todos eles em um incurável ceticismo. 
(cf. Chibeni, 2008; Cummins, 2005), não me alongarei sobre ele aqui, dedicando-me apenas a apontar algumas de suas implicações para o tema da natureza da gravitação.

A implicação mais importante e imediata é obvia: se os corpos não têm nenhum poder causal, não têm, em particular, o poder de atrair outros corpos gravitacionalmente. Curiosamente, Berkeley demora um pouco para chegar a essa conclusão, que só aparece explicitamente em 1720, no Do movimento (De motu). 9 Nos Princípios do conhecimento, a existência de forças é posta em questão, porém com base em um argumento diferente, como veremos logo mais. A inatividade dos corpos é evocada por Berkeley unicamente para refutar o mecanicismo corpuscularista de Descartes. Ao insistir em combater essa doutrina Berkeley imita Newton, embora seus argumentos sejam completamente diferentes. Como vimos, o argumento de Newton é mais específico e técnico; o mecanicismo cartesiano não explica bem, e é incompatível com os fenômenos astronômicos, dentro da nova dinâmica inercial. Já para Berkeley, o problema é que, se os corpos não podem agir causalmente uns sobre os outros, fica perdida a motivação central da postulação de corpos microscópicos, se sua função for, como propõe o corpuscularismo, explicar causalmente aquilo que vemos no nível macroscópico. Vale a pena, a esse respeito, examinar este trecho.

Um dos grandes fatores que nos induz a considerarmo-nos ignorantes acerca da natureza das coisas é a opinião corrente de que cada coisa inclui em si a causa de suas propriedades; ou que há nos objetos uma essência interna que é a fonte de suas qualidades perceptíveis, e da qual elas dependem. Alguns pretenderam dar conta das aparências por meio de qualidades ocultas; ultimamente, porém, são usualmente explicadas em termos de causas mecânicas, a saber, forma, movimento, peso e qualidades semelhantes de partículas imperceptíveis; quando, na verdade, não há outro agente ou causa eficiente senão o espírito, sendo evidente que o movimento, bem como todas as outras ideias, é perfeitamente inerte (ver a seção 25). Portanto, esforçar-se para explicar a produção de cores ou sons pela forma, movimento, tamanho e coisas parecidas será trabalho vão. Vemos, de fato, que as tentativas desse tipo não são nada satisfatórias. Isso se pode dizer em geral de todos os casos em que uma ideia ou qualidade é dada como a causa de outra. Nem preciso dizer quantas hipóteses e especulações são eliminadas, e quanto o estudo da natureza é simplificado por essa doutrina (Princípios, 1975, § 102).

9 Nessa obra, a primeira crítica à força de gravidade é essencialmente a mesma que a feita nos Princípios do conhecimento (a ser vista logo abaixo). É somente a partir do § 22 que Berkeley passa a evocar a tese da inatividade causal dos corpos para atacar a suposição da existência dessa força e de quaisquer outras. Uma análise extensa da rejeição berkeleyana do realismo dinâmico é empreendida em Downing, 2005. A autora aponta vários outros argumentos, além dos aqui apresentados, que fundamentam essa rejeição. 
Mas Berkeley não se limitou a criticar o mecanicismo cartesiano, que em seu tempo já havia sofrido desgaste considerável. Ele tinha um alvo mais vivo e importante. Já no parágrafo seguinte registra, corretamente, que "o grande princípio mecânico agora em voga é a atração", em clara alusão à força gravitacional introduzida na mecânica por Newton. Passa então a criticar esse princípio. Quando se esperaria que o rejeitasse com base no argumento geral contra qualquer hipótese que envolva poderes ativos nos corpos, apresentado no parágrafo precedente para rejeitar o mecanicismo, essa primeira crítica à noção de força de atração tem por base, simplesmente, o fato de não ser uma noção empírica. A crítica é, pois, a mesma que a que foi feita ao espaço e tempo absolutos (cf. Princípios, § 97-98, §110-117), e vale também, como vai ficando claro ao longo dos textos, para toda suposição de forças reais entre os corpos, sejam de atração ou repulsão, de qualquer natureza. Leiamos o parágrafo na íntegra.

O grande princípio mecânico agora em voga é a atração. Que uma pedra caia para a Terra, ou o mar inche em direção à Lua parece a alguns ser suficientemente explicado por esse princípio. O que nos esclarece, porém, dizer que isso se dá pela atração? Será porque esse termo signifique a maneira da tendência, que é o puxar mútuo dos corpos, ao invés de serem impelidos ou empurrados uns para os outros? Nada, porém, se determina acerca do modo de ação, e ela pode (por tudo o que sabemos) ser tão verdadeiramente denominada impulso, ou empurrão, como atração. Igualmente, vemos que as partes do aço se grudam firmemente umas às outras, e isso também se pretende explicar pela atração. Porém, neste caso, como nos outros, não percebo nada significado pela atração senão o efeito ele mesmo. Pois quanto à maneira da ação pela qual esse efeito é produzido, ou à causa que o produz, ela não é sequer parte do objetivo [da filosofia natural] (Princípios, § 103).

A posição de Berkeley é, portanto, que o único referente empiricamente determinado do termo "atração" é o movimento de aproximação dos corpos uns em direção dos outros. É isso tudo o que percebemos. A suposta força, o agente causal do movimento, não está disponível na experiência e, se o termo for empregado nesse sentido, não terá significado genuíno.

No Do movimento, de 1720, Berkeley acrescenta um argumento para pôr em dúvida a possibilidade de se contornar essa objeção à interpretação realista da força de atração gravitacional (e das forças em geral) sustentando-se que ela poderia ser inferida a partir dos fenômenos. Essa era justamente a posição de Newton. Newton poderia conceder que a força de gravidade não é empiricamente acessível; mas, como vimos, defendeu explicitamente, e com total uniformidade ao longo de sua carreira, que ela pode ser inferida dos fenômenos e, também, inferida demonstrativamente. O que Newton 
tinha em mente era, certamente, a dedução da existência de uma força para produzir os fenômenos da queda dos corpos, dos movimentos planetários etc., a partir do fato de serem movimentos acelerados (em módulo ou direção). Mas isso não basta. A dedução pressupõe a lei da inércia e, no nível quantitativo (para se chegar à fórmula da força de gravidade), também a segunda lei do movimento. Ora, tais leis são princípios teóricos, e colocar as coisas nesses termos simplesmente transfere para eles a questão da fundamentação do conhecimento da mecânica. Embora Newton tenha mantido que, a seu turno, tais princípios foram "inferidos dos fenômenos e depois tornados gerais por indução" (Newton, 1934, p. 547), é claro que essa tese não pode ser aceita com a mesma tranquilidade por um epistemólogo de nossos dias. Cabe, pois, a Berkeley o pioneirismo de haver percebido que, de uma perspectiva empirista, havia um problema sério - e, a seu ver, incontornável - no estabelecimento da existência da força de gravitação, ou de qualquer outra, mediante inferências feitas a partir dos fenômenos. $\mathrm{O}$ argumento formulado em Do movimento põe a descoberto a dependência teórica ineliminável de qualquer inferência da existência de forças e, portanto, o seu caráter, por assim dizer, convencional.

Resta discutir a causa da comunicação dos movimentos. A maioria das pessoas pensa que a força impressa sobre um corpo móvel é a causa do seu movimento. Contudo, que elas não atribuem uma causa conhecida ao movimento, distinta do corpo e do movimento, torna-se claro pelo argumento acima. É evidente, além disso, que a força não é uma coisa certa e determinada, pois grandes homens desenvolveram sobre ela muitas opiniões diferentes, por vezes contrárias, e mesmo assim seus resultados alcançaram a verdade. Pois Newton afirma que a força impressa consiste apenas na ação, e é a ação exercida sobre um corpo que muda seu estado, e não permanece após a ação. Torricelli argumenta que uma certa quantidade ou agregado de forças impressas por percussão é recebida pelo corpo móvel, e nele permanece, constituindo o impetus. Borelli e outros dizem quase o mesmo. Mas embora Newton e Torricelli pareçam discordar entre si, cada um deles desenvolveu uma perspectiva consistente, e o fato é suficientemente bem explicado por ambos. Pois todas as forças atribuídas aos corpos são hipóteses matemáticas, tanto quanto o são as forças de atração nos planetas e no sol. Mas entidades matemáticas não possuem essência estável na natureza das coisas; e elas dependem da noção de quem as define. Por isso a mesma coisa pode ser explicada de diferentes maneiras (De motu, § 67).

Esse argumento é interessante por independer de outros princípios do sistema de Berkeley, aplicando-se, além disso, a hipóteses quaisquer, que não exclusivamente 
sobre a existência de forças, tanto assim que é bastante usado hoje em dia pelos antirrealistas científicos, sob a denominação de argumento da equivalência empírica das hipóteses sobre inobserváveis. Essa equivalência implica, dentro do referencial empirista, que tais hipóteses são subdeterminadas pela evidência empírica e que, portanto, não poderiam contar como conhecimento seguro sobre a realidade ela mesma.

Uma forma fácil de exemplificar o engenhoso argumento de Berkeley foi concebida - embora sem referência a Berkeley - por Brian Ellis, em um artigo sobre a mecânica newtoniana em que a questão da existência objetiva das forças é analisada (cf. Ellis, 1965). Ellis construiu um sistema de dinâmica empiricamente equivalente ao newtoniano, ou seja, que reproduz exatamente todas as suas predições experimentais, mas em que não há forças gravitacionais. Aideia de Ellis foi a de "embutir" a gravitação numa lei de "inércia" modificada, do seguinte modo (cf. Chibeni, 1999):

Primeira Lei: Todo corpo tem um componente de aceleração relativa na direção de todo outro corpo do universo diretamente proporcional à soma de suas massas e inversamente proporcional ao quadrado da distância que os separa, a menos que ele esteja sob a ação de uma força;

Segunda Lei: $\mathbf{F}$ = ma (onde a é a aceleração relativa à aceleração natural: $\mathbf{a}=\mathbf{a}$ absoluta - anatural $)$,

onde por "aceleração absoluta" entende-se a aceleração relativamente a um referencial inercial newtoniano e por "aceleração natural”, a aceleração que, no sistema newtoniano, seria atribuída à força de gravidade, sendo calculada pela fórmula de Newton.

A tese berkeleyana da impossibilidade de se inferir, em qualquer sentido forte, a força de atração gravitacional unicamente a partir dos fenômenos do movimento é, pois, uma tese bastante bem fundamentada. Além disso, Berkeley mantém, em contraste claro com Newton, que a mecânica newtoniana pode prescindir da noção de força, como também havia sustentado (cf. Princípios, § 97-98, §110-117), que pode prescindir das noções de espaço e tempo absolutos. O filósofo natural poderia se limitar a registrar cuidadosamente os fenômenos (posições, velocidades, acelerações), descobrir as regularidades existentes entre eles, formulando-as em leis fenomenológicas - como a lei galileana da queda dos corpos - e, a partir dessas leis, fazer duas coisas: prever a ocorrência de certos fenômenos a partir de outros fenômenos, e explicar a ocorrência dos fenômenos por sua subsunção a essas leis gerais. Esta última tarefa pressupõe a adoção de uma nova noção de explicação científica, que efetivamente coincide com a que, no século xx, veio a ser chamada de noção nomológico-dedutiva da explicação (cf. Chibeni, 2008), e que se contrapõe à noção tradicional, segundo a qual explicar é apontar causas. 
Recorrendo novamente a uma análise contemporânea para ilustrar e corroborar o ponto de Berkeley, poderíamos, desta vez, mencionar Ernst Mach. O objetivo de Mach era semelhante ao de Berkeley, a saber, conferir clareza conceitual e teórica à mecânica newtoniana e, principalmente, livrá-la de noções “metafísicas”, como as de espaço e tempo absolutos e a própria noção de força, entendida como ente real. Para tanto, propôs uma reformulação teórica, em que se distinguem explicitamente as "proposições experimentais" das "definições" (cf. Mach, 1974). Nessa divisão, aquilo que usualmente se considera a segunda lei de Newton passa a ser entendido não como lei, mas como mera abreviação para o produto da massa pela aceleração. Torna-se, pois, claro que tal conceito é dispensável, do ponto de vista físico (embora não talvez do pragmático; cf. Chibeni, 1999).

Retomando o exame do $\S 6$, acima citado, vemos que nele Berkeley propõe algo que difere da posição mais radical que havia defendido nos Princípios do conhecimento. Berkeley mostra-se agora tolerante com relação à introdução de hipóteses sobre forças na filosofia natural, desde que não sejam tomadas literalmente, e sim interpretadas como "matemáticas" - exatamente como Newton propôs nos comentários às suas definições de quantidades de forças centrípetas. A introdução dessa interpretação "matemática" das forças representa um tipo de abrandamento da posição forte exposta nos Princípios do conhecimento e nos parágrafos iniciais do próprio Do movimento; podemos conjeturar que pode ter surgido do reconhecimento, por parte de Berkeley, de que elas são um elemento teórico central na mecânica de Newton, que exibia sucesso cada vez mais impressionante. Berkeley teria avaliado que seria melhor encontrar um modo de manter a teoria newtoniana na forma original, mas reinterpretando filosoficamente as referências a forças nela feitas. A proposta do $§ 103$ dos Princípios do conhecimento também envolve uma reinterpretação das forças: por força dever-se-ia entender só os efeitos empíricos. Mas, como estes são inteiramente acessíveis e descritos em terminologia própria, o melhor seria simplesmente não mais falar em forças na mecânica. Essa é, pois, uma reinterpretação eliminativista. A proposta que aparece no Do movimento é bem diferente: força não denota nada (nem mesmo efeitos empíricos), o conceito tendo função puramente instrumental na teoria, ou seja, nas palavras de Berkeley, são "hipóteses matemáticas" ou "ficções" úteis para efetuar cálculos, melhorando o poder preditivo da teoria. Essa proposta foi chamada de instrumentalismo por Karl Popper $\left(1972\right.$, cap. 3, p. 97-119). ${ }^{10}$

10 Nessa famosa análise crítica do instrumentalismo, Popper aponta Berkeley como um de seus proponentes mais importantes. Popper afirma que a adoção do instrumentalismo por parte de Berkeley era motivada pelo desejo de evitar que a teoria mecânica de Newton pudesse ser vista, caso fosse interpretada de forma realista, como "uma séria competidora da religião" (1972, p. 98). Essa tese, para a qual Popper não fornece argumentos, não me parece correta. Como estou tentando mostrar neste trabalho, o instrumentalismo de Berkeley, além de bastante circunscrito, 
Na história da filosofia natural, houve, antes de Berkeley, uma famosa defesa do instrumentalismo - talvez pioneira - no prefácio de Andreas Osiander ao De revolutionibus, de Copérnico de 1543. Ali, Osiander propôs que os elementos não-empíricos da astronomia - a rotação real da Terra ou do Sol, os epiciclos, deferentes etc. - fossem interpretados como meros artifícios teóricos. Essa era uma forma de dissolver o cerne da polêmica acerca da astronomia copernicana, possibilitando que a teoria fosse aproveitada integralmente, por seus méritos preditivos. O que houvesse nela de não empírico deveria ser mantido, mas interpretado como "hipóteses" ou invenções sem pretensão à verdade (cf. Loparic, 1980). A nova posição de Berkeley parece ser exatamente essa, como se nota no final do trecho do $\S 67$ do Do movimento, transcrito acima. Na verdade, a interpretação instrumentalista havia sido introduzida bem antes no começo desse livro:

Força, gravidade, atração e termos desse tipo são úteis aos raciocínios e cálculos sobre o movimento e corpos em movimento, não porém para entender a natureza simples do movimento em si próprio, ou para indicar tais e tais qualidades distintas. A atração, por exemplo, foi introduzida por Newton não como uma qualidade física verdadeira, mas apenas como uma hipótese matemática (De motu, $\S 17)$.11 $^{11}$

Afirmações do mesmo teor são feitas nos parágrafos seguintes, ${ }^{\mathbf{1 2}}$ sempre com base em considerações gerais sobre a não pertinência de atribuição de poderes causais aos corpos. Apenas no $§ 67$ é que a defesa dessa posição é feita, como vimos, com base no poderoso argumento da equivalência empírica das hipóteses sobre as causas do movimento. Que forças são meras "hipóteses matemáticas", e não entes físicos cuja realidade possa ser determinada, decorre do fato de que são possíveis, e realmente existem, várias concepções incompatíveis do que elas sejam.

tem sua principal motivação e ponto de apoio na tese da inatividade causal dos corpos, que a seu turno deriva, em sua face epistemológica (ou seja, que, ainda que existissem, os poderes causais dos corpos não seriam acessíveis à nossa cognição), do empirismo estrito adotado por ele. (Cf., para mais detalhes, Chibeni, 2010.)

11 Note-se a significativa referência aos comentários de Newton às definições de quantidades de forças centrípetas. Por outro lado, nas obras de Berkeley não há nenhuma menção aos textos de Newton que indicam adesão, por parte dele, à interpretação realista das forças - que, como vimos, são numerosos. Estamos, provavelmente, diante de uma deliberada seleção feita por Berkeley, em vista dos propósitos que tinha.

12 Já no § 18, Berkeley dá um exemplo bastante conhecido e convincente, o da "composição e resolução de uma força direta qualquer em forças oblíquas por meio da diagonal e dos lados do paralelogramo”. No § 28, forças são novamente qualificadas de "hipóteses matemáticas", e no §39, de "ficções", advertindo Berkeley que, embora fictícias, são de "utilidade essencial para as teorias”. Essa mesma utilidade é sublinhada em Alciphron (§ ₹). 
Nesse mesmo $§ 67$ há outro ponto importante, que merece alguns comentários. É que Berkeley afirma, de forma intrigante, que as hipóteses “matemáticas” que estava considerando explicam suficientemente os fatos empíricos de seu domínio, mesmo enfatizando que elas "não possuem essência estável na natureza", sendo apenas construções “abstratas”. Ora, isso representa um acréscimo importante à noção nomológico-dedutiva de explicação, tal qual caracterizada nos Princípios do conhecimento, em que a base da dedução (e, portanto, da explicação) era uma lei da natureza de caráter empírico, obtida indutivamente. Agora, se de fato a posição de Berkeley for a que se expressa na aludida frase do $§ 67$, essa base poderá ser também uma hipótese que envolva elementos explicitamente dados como fictícios. Essa modificação parece tornar a proposta berkeleyana de explicação científica ainda mais discrepante do senso comum (sendo que a noção nomológico-dedutiva já representa um distanciamento importante com relação a ele). Como se poderá considerar um fato explicado simplesmente mostrando-se que ele decorre dedutivamente de uma proposição geral inventada, fictícia, sem pretensões à realidade?

Vejamos duas outras passagens que indicam que essa parece, de fato, ser a nova posição de Berkeley. A primeira está logo adiante, no mesmo Do movimento.

Portanto, uma coisa é explicada fisicamente, não se assinalando sua causa realmente ativa e incorpórea, porém mostrando-se sua conexão com princípios mecânicos, tais como ação e reação são sempre opostas e iguais (De motu, § 69).

Crucial aqui é que o exemplo dado de princípio mecânico é sobre forças e, portanto, acerca de algo que, segundo Berkeley, não tem "essência estável na natureza", sendo mero artifício teórico. ${ }^{\mathbf{1 3}}$ Outra passagem expressiva que vai na mesma direção encontra-se na última obra de Berkeley, Siris, de 1744:

A natureza parece melhor conhecida e explicada por atrações e repulsões do que por aqueles outros princípios mecânicos de tamanho, forma e coisas parecidas; ou seja, por Sir Isaac Newton, do que por Descartes (Siris, § 24,3).

Essa afirmação tem uma aparência capaz de seduzir um leitor realista desavisado. Quando, porém, leva-se em conta a tese berkeleyana do caráter puramente instrumental dos conceitos dinâmicos - tese essa que ele manteve inalterada, desde sua formulação no Do movimento até o Siris (onde ela é reafirmada explicitamente em diversas oca-

13 Observe-se a discrepância da posição de Berkeley relativamente à de Newton, que, como vimos, considerava que seus princípios mecânicos haviam sido demonstrados a partir dos fenômenos e, nessa medida, legitimados como reais. 
siões) -, a assertiva de Berkeley colide frontalmente com o senso comum. Teria, com certeza, desagradado duplamente o próprio Newton, que nem gostava de hipóteses de uma forma geral, fazendo questão de enfatizar que a sua força de atração gravitacional foi "demonstrada" a partir dos fenômenos, e muito menos aceitaria que se possa explicar algo a partir de hipóteses que são meras ficções teóricas.

Observe-se, porém, que a "explicação" por meio de proposições fictícias não é de aplicação geral na filosofia natural, segundo Berkeley. Ocorre que, no Siris, Berkeley examina e formula hipóteses sobre constituintes inobserváveis do mundo físico e não interpreta, ao que tudo indica, tais hipóteses como artifícios teóricos, mas sim como candidatas genuínas à representação da realidade física (cf. Chibeni, 2010). Podemos, então, concluir que a interpretação instrumentalista das hipóteses se circunscreve às hipóteses dinâmicas (cartesianas, newtonianas, ou qualquer outra), pois é nesse caso que a interpretação realista das hipóteses conflita com um dos pilares da filosofia natural de Berkeley, a tese da inatividade dos corpos. Em todos os casos, porém, o modus operandi da ciência parece ser o mesmo, o de registrar fenômenos, descobrir regularidades formuláveis em termos fenomenológicos, avançar além desse nível, formulando hipóteses explicativas - explicativas em um sentido neutro, de se poder deduzir os fenômenos a partir das hipóteses, independentemente de como elas sejam interpretadas - e, finalmente, avaliar tais hipóteses, justamente procedendo-se à comparação de suas capacidades explicativas (simplicidade da hipótese, escopo de fenômenos explicados, predição de fenômenos novos a partir da hipótese etc.). O fazer ciência, segundo Berkeley, é uma atividade que se assemelha muito ao fazer ciência real; a diferença está na interpretação filosófica do que se faz.

\section{ComentáRIos Finais}

A introdução do princípio de inércia, por Galileo e Descartes, alterou profundamente o referencial teórico no qual se deveriam buscar explicações para os fenômenos do movimento. Classes importantes de movimento, como a chamada "queda dos graves" e o movimento dos corpos celestes, passaram a requerer explicações por meio de causas eficientes. A determinação dessas causas constituiu um dos problemas centrais da nova filosofia natural. Descartes, para quem o problema se tornou particularmente agudo, ofereceu uma resposta que se tornou rapidamente aceita, dada sua inserção na visão de mundo mecanicista que, ao menos à primeira vista, permitia a compreensão do mundo ao longo de linhas claras e, por assim dizer, de senso comum. Nela toda ação causal ocorre simplesmente pelo contato de um corpo com outro, algo que verificamos em nossa experiência cotidiana. A resposta cartesiana propunha, assim, a existência 
de corpos invisíveis - formando turbilhões - que empurrariam a pedra em sua queda, ou o planeta na direção do Sol. A existência desses turbilhões de matéria sutil foi explicitamente introduzida por Descartes a título de hipótese, e sua justificação dependia, segundo ele, da avaliação a posteriori de seus méritos explicativos e preditivos.

Essa proposta desagradou duplamente a Newton. Primeiro, do ponto de vista metodológico/epistemológico, ele considerava ilegítimo o uso de hipóteses em tal contexto e com esses objetivos. Alimentava um padrão epistemológico mais alto, segundo o qual explicações para os fenômenos naturais precisariam ser "demonstradas" a partir dos fenômenos. Depois, levantou objeções sérias à hipótese dos vórtices, ao mostrar que esse meio material, caso existisse, obstaria os movimentos dos corpos celestes, visto ter de possuir inércia, como qualquer corpo material. Com isso, Newton reabriu o problema explanatório central da mecânica. Ao mesmo tempo, avançou na direção de sua solução. Newton acreditou firmemente haver demonstrado a existência de um tipo diferente de causa para os ditos movimentos não inerciais - uma força de atração universal. Tudo estaria bem, não fossem dois problemas. Primeiro, a demonstração oferecida por Newton não se apoia exclusivamente em fenômenos, dependendo também das leis dinâmicas. Se estas por alguma razão forem questionadas, a demonstração perderá a sua relevância. Esse problema, porém, aparentemente não foi sequer notado por Newton, ou mesmo por seus principais críticos contemporâneos, visto que, segundo o próprio Newton, as leis dinâmicas teriam, a seu turno, sido derivadas a partir dos fenômenos por “indução". É claro que essa resposta não satisfaz a qualquer um de nós, seus leitores filosóficos do século xxI, mas esse é outro assunto.

O segundo problema com a tese newtoniana da existência da força de gravitação - este sim notado por Newton e seus críticos, tornando-se foco de viva controvérsia - é que era um tipo de causa que não podia, ao menos aparentemente, ser encaixada no referencial mecanicista estrito, em que toda ação causal no mundo físico ocorre por contato. Quanto a isso, a posição de Newton mostrou-se difícil de interpretar. Por um lado, rejeitou, em termos tão cabais como os de seus principais críticos, Huygens e Leibniz, a possibilidade de uma "ação a distância", pela qual um corpo pudesse operar sobre outro corpo distante sem a intermediação de outros corpos. Mas, por outro lado, Newton não se mostrou capaz de oferecer uma explicação para a gravitação que pudesse evitar a acusação de que também seria um tipo de ação a distância. Na verdade, embora Newton tenha privadamente tentado conceber uma explicação, e apresentado um esboço de explicação como uma das questões da Óptica, explicitamente declinou essa tarefa no famoso escólio geral dos Princípios matemáticos. Isso levou os críticos a acusarem-no de, ao deixar a questão em aberto, efetivamente retroceder à perspectiva escolástica das "qualidades ocultas". 
Tendo passado em revista e comentado brevemente essas questões, na introdução e na primeira seção deste trabalho, dedicamo-nos em seguida a examinar as posições de dois outros filósofos contemporâneos de Newton, menos citados do que Huygens e Leibniz quando se trata de discutir os fundamentos da gravitação, mas não menos importantes, dada a relevância de suas análises epistemológicas da questão. Primeiramente, na seção 2, consideramos o caso de John Locke. Embora, como todo mundo, admirador de Newton, Locke efetivamente divergiu dele quanto a um ponto importante: o papel das hipóteses na filosofia natural. Como vimos, a posição de Locke é mais próxima da de Descartes, ao admitir que hipóteses possam ser formuladas com fins explicativos e legitimadas a posteriori, pelo exame de suas virtudes comparativas, relativamente a outras hipóteses. Não é certo, porém, que Locke tenha percebido que a força gravitacional newtoniana deveria ser contada como uma hipótese. Parece, ao contrário, que Locke foi um dos muitos que aceitaram de forma acrítica a estória newtoniana da dedução dessa força a partir dos fenômenos. Locke estava plenamente informado, porém, da questão de nível superior, referente à explicação da própria força gravitacional e, quanto a ela, adotou uma postura que a nós pode parecer surpreendente. Dado que - como o próprio Newton se encarregou de enfatizar - essa explicação não se poderia dar pelo contato superficial com outros corpos e, provavelmente desconhecendo as tentativas de Newton de encontrar uma explicação que evitasse a ação a distância pela postulação de um fluido sutil capaz de penetrar os corpos, Locke resignouse a propor que esse poder de atração seria um poder "superadicionado" por Deus à matéria, de forma inteiramente incompreensível por nossos entendimentos. Locke traçou analogias dessa tese com teses semelhantes que propôs, ou pelo menos considerou possíveis, relativas a outros poderes de corpos e espíritos que não podem ser inferidos daquilo que sabemos acerca de tais substâncias. Embora naquela época tal proposta certamente fosse mais aceitável do que na nossa, não parece ter sido adotada por ninguém que trabalhava para fazer avançar o conhecimento da filosofia natural. Efetivamente, acabou contando como uma expressão típica da inclinação cética propiciada pela adoção de uma perspectiva empirista quanto a esse domínio do conhecimento.

Na seção 3, examinamos, por fim, as posições de George Berkeley, estas sim vindo a produzir frutos positivos nas discussões sobre o estatuto epistemológico da gravitação, embora essa produção tivesse que amadurecer em silêncio por quase dois séculos. Primeiramente, coube a Berkeley o pioneirismo de efetivamente reconhecer que a tese newtoniana da demonstração da existência dessa força não era aceitável. Sendo um item teórico, não poderia ser introduzido de outra forma senão como uma hipótese. Mas embora Berkeley não tenha feito uma proscrição geral das hipóteses na filosofia natural, essa hipótese em particular - ou melhor, ela e quaisquer outras hipóteses dinâmicas - não poderia ser aceita, pois conflitava com uma das mais importantes 
consequências da filosofia de Berkeley, a inatividade causal dos corpos. Diante disso, Berkeley propôs, inicialmente, nos Princípios do conhecimento, uma reinterpretação eliminativista da gravitação. Por gravitação dever-se-ia entender apenas os fenômenos de aceleração dos corpos, segundo a fórmula de Newton. Essa proposta seria retomada mais tarde, mutatis mutandis, e com muito mais sofisticação formal, por Ernst Mach, no final do século xix. No entanto, Berkeley posteriormente modificou sua proposta, no Do movimento, obra em que defendeu explicitamente e com muita engenhosidade a reinterpretação instrumentalista da força de gravidade e das forças em geral. Essa posição tinha um precedente importante no prefácio de Osiander ao livro de Copérnico, mas só frutificaria no século xx, em geral associada a pacotes filosóficos antirrealistas mais amplos para a compreensão do conhecimento científico, pacotes esses que apresentam vários outros pontos de contato com a filosofia natural de Berkeley.

Os defensores dessas teorias da ciência antirrealistas usualmente argumentam que o instrumentalismo - e outras formas de antirrealismo sobre inobserváveis - é uma maneira simples e eficaz de livrar a filosofia natural das insolúveis disputas metafísicas sobre a realidade última das coisas, e que, assim, sua adoção efetivamente pode contribuir para o avanço mais desimpedido do conhecimento científico - ou da "filosofia experimental", como diriam Berkeley e o próprio Newton (cf. Shapiro, 2004). Filósofos da vertente realista contra-argumentam, dizendo que, ao contrário, a busca de explicações para os fenômenos naturais é um dos mais importantes desiderata da filosofia natural - ou o mais importante deles, como defendia Aristóteles -, e que nessa busca temos de pagar o preço de introduzir hipóteses sobre níveis inobserváveis da realidade, embora com isso percamos o ideal da obtenção de certeza absoluta daquilo que propomos. Sustentam, ademais, que essa busca de explicações é um dos motores mais poderosos do avanço do conhecimento científico.

Essa é uma disputa filosófica de amplas dimensões, cuja análise escapa ao escopo do presente trabalho. No entanto, não nos podemos furtar de observar que, a favor da posição realista, conta o fato histórico de que a ciência moderna efetivamente caminhou no sentido de um aprofundamento cada vez maior das conjeturas cientificamente bem formuladas e controladas acerca das causas inobserváveis dos fenômenos naturais, e que essa tendência acentuou-se ainda mais na ciência contemporânea, em que pesem os argumentos poderosos que alguns dos pais de uma de suas duas mais importantes teorias, a mecânica quântica, forneceram para uma interpretação antirrealista - e em especial instrumentalista - dessa teoria. Nessa evolução histórica, a questão da gravitação voltou a preocupar cientistas e filósofos a partir do final do século xIX, sendo que novidades importantes surgiram com o advento da teoria da relatividade geral, em 1915. Não obstante sua importância, esse assunto não poderá ser analisado 
aqui. Fica, como uma observação final, que, quaisquer que sejam as posições que adotemos sobre essa nova face do problema da gravitação, somos todos, ainda hoje, motivados pelo fascinante desafio físico e filosófico lançado por Newton há mais de trezentos anos.@

\author{
Silvio Seno Ghibeni \\ Departamento de Filosofia, \\ Instituto de Filosofia e Ciências Humanas, \\ Universidade Estadual de Campinas, São Paulo, Brasil. \\ chibeni@unicamp.br \\ Newton, Locke and Berkeley's \\ positions on the nature of gravitation
}

\begin{abstract}
Newton's defence, in the Principia, of the existence of a universal force of gravity immediately gave rise to a wave of philosophical doubts and objections. His own remarks on the nature of gravitation are not easily amenable of a consistent, uniform interpretation. This paper begins by reviewing briefly these remarks. Its primary objective is, however, to examine how this important scientific issue contributed to demarcate two main epistemological positions on the status of scientific hypotheses transcending immediate experience. In Newton's time, two exponents of these positions were, respectively, Locke and Berkeley. Intriguingly, Newton fuelled both the Berkeleyan, instrumentalist interpretation, and the Lockean, realist interpretation. On the one hand, immediately after offering the definitions of "quantities of centripetal forces" (Definitions 6-8), he warned that he was treating these forces "mathematically", without pronouncing on its physical status. This remark lends support to Berkeley's anti-realist interpretation of forces, as Berkeley himself was keen to point out. But in the General Scholium, at the end of the book, Newton declared that he could "explain" certain important phenomena of motion by the force of gravity, although he had not yet been able to explain the cause of this force, adding, famously, that he would "feign no hypotheses" about this issue. A natural, realist interpretation of this statement is that Newton believed that he could infer, from the phenomena, the existence of gravity, as a real, causal physical agent, but that he had not yet succeeded in discovering the cause of this cause. In discussing the shortcomings and advantages of these opposing views, we indicate that although the realist interpretation appears to do more justice to the actual development of physics after the Principia, Berkeley's interpretation has the philosophical merit of representing a firmer adherence to empiricism, a position valued, in one way or another, by all parties involved in the dispute on the nature of gravitation.
\end{abstract}

KEYwords $•$ Force of gravity. Newton. Locke. Berkeley. Scientific realism. Instrumentalism. 


\section{REFERÊNGIAS BIBLIOGRÁFICAS}

Adam, C. \& Tannery, P. (Ed.). Oeuvres de Descartes. Paris: Vrin, 1971. v. 9.

Ayers, M. R. (Ed.). Philosophical works of Georges Berkeley. London: Everyman, 1975.

. Mechanism, superaddition, and the proof of God's existence in Locke's Essay. The Philosophical

Review, 90, 2, p. 210-51, 1981.

.Locke. Epistemology and ontology. London: Routledge, 1991.

Barra, E. S. O. Em que sentido Newton pode dizer "hypotheses non fingo"? Cadernos de História e Filosofia da Ciência, Série 3, 5, 1-2, p. 221-45, 1995 .

. A primazia das relações sobre as essências: as forças como entidades matemáticas nos Principia de

Newton. Scientiae Studia, 8, 4, p. 547-69, 2010.

Berkeley, G. Alciphron, or the minute philosopher. 1732. In: Complete works of Georges Berkeley. v. 5 .

Charlosttesville: InteLex Cooporation. (Série "Past Masters) (Alciphron)

.Siris. 3 ed. $175^{2}$ [1744]. In: Complete works of Georges Berkeley. v. 3. Charlosttesville: InteLex Cooporation. (Série "Past Masters) (Siris)

. Philosophical Commentaries. Ayers, M. R. (Ed.). Philosophical works of Georges Berkeley. London:

Everyman, 1975 [1707-1708]. p. 3०5-4,12. (Comentários)

. A treatise concerning the principles of human knowledge. In: Ayers, M. R. (Ed.). Philosophical

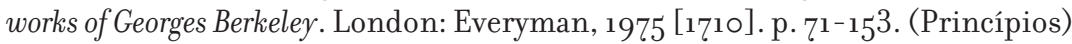

. Three dialogues between Hylas and Philonous. In: Ayers, M. R. (Ed.). Philosophical works of Georges

Berkeley. London: Everyman, 1975 [1713]. p. 155-252.

. De motu. Tradução A. A. Luce; revisão M. R. Ayers. In: Ayers, M. R. (Ed.). Philosophical works of Georges Berkeley. London: Everyman, 1975 [1720].p. 253-76. (De motu)

CAJori, F. An historical and explanatory appendix. In: Newton, I. Mathematical principles of natural philosophy. Tradução A. Motte; revisão F. Cajori. Berkeley/Los Angeles: University of California Press, 1934. p. 627-8o.

CaLA Vitery, F. E. La cuestión 31 de la Óptica o el programa de las fuerzas en la filosofía mecánica. Scientiae Studia, 4, 2, p. 177-220, 2006.

Chibeni, S. S. A fundamentação empírica das leis dinâmicas de Newton. Revista Brasileira de Ensino de Física, 21, 1, p. 1-14, 1999.

. Locke on the epistemological status of scientific laws. Principia, 9, 1-2, p. 19-4,1, 2005.

. Locke e o materialismo. In: Moraes, J. Q. K. (Org.). Materialismo e evolucionismo. Campinas: CLE, 2007. p. 163-92. (Coleção CLE, v. 47).

. Berkeley: uma física sem causas eficientes. Cadernos de História e Filosofia da Ciência, Série 3, 18, 2,

p. $357^{-90,2008 .}$

. Berkeley e o papel das hipóteses na filosofia natural. Scientiae Studia, 8, 3, p. 389-419, 2010.

. Locke e a distinção entre qualidades primárias e secundárias. No prelo.

Cimatterbaugh, K. The causation debate in modern philosophy, 1637-1739. New York: Routledge, 1999.

Cohen, I. B. Hypotheses in Newton's philosophy. Physis, 8, p. 163-84, 1966.

Conen, I. B. \& Sмith, G. E. (Ed.). The Cambridge companion to Newton. Cambridge: Cambridge University Press, 2002.

Colodny, R. B. (Ed.). Beyond the edge of certainty. Englewood Cliffs, N.J.: Prentice Hall, 1965.

Cummins, P. D. Berkeley on minds and agency. In: Winkler, K. (Ed.). The Cambridge companion to Berkeley. Cambridge: Cambridge University Press, 2005. p. 190-229.

Descartes, R. Les principes de la philosophie. In: Adam, C. \& Tannery, P. (Ed.). Oeuvres de Descartes. Paris: Vrin, 1971 [1644]. v. 9.

Dijksterhuis, E. J. The mechanization of the world picture. Princeton: Princeton University Press, 1986. 
As posições de Newton, Logke e Berkeley sobre a natureza da gravitação

Downing, L. Berkeley's natural philosophy and philosophy of science. In: WinkLer, K. (Ed.). The Cambridge companion to Berkeley. Cambridge: Cambridge University Press, 2005. p. 23o-65.

Ellis, B. The origin and nature of Newton's laws of motion. In: Colodny, R. B. (Ed.). Beyond the edge of certainty. Englewood Cliffs, N.J.: Prentice Hall, 1965. p. 29-67.

FARR, J. The way of hypotheses: Locke on method. Journal of the History of Ideas, 48, 1, p. $5^{1^{-}} 7^{2}, 1987$.

JANIAK, A. Newton and the reality of force. Journal of the History of Philosophy, 45, 1, p. 127-47, 2007.

LAUDAN, L. The nature and sources of Locke's view on hypotheses. Journal of the History of Ideas, 28, p. 21123,1967 .

Locke, J. Elements of natural philosophy. In: TEGG, T. et al. (Ed.). The works of John Locke. Dublin: Cumming, 1823. v. 3, p. 3o1-3o.

. Reply to the Bishop of Worcester's answer to his second letter. In: TEGG, T. et al. (Ed.). The works of John Locke. Dublin: Cumming, 1823. v. 4, p. 191-498. (Segunda resposta)

Some thoughts concerning education. In: TEGG, T. et al. (eds.). The works of John Locke. Dublin:

Cumming, 1823.v. 9, p. 1-205. (Pensamentos)

. An essay concerning human understanding. Introdução e notas P. H. Nidditch. Oxford: Clarendon Press, 1975. (Ensaio)

. Method. In: FArR, J. The way of hypotheses: Locke on method. Journal of the History of Ideas, 48, 1, p. 70-2, 1987. (Método)

Loparic, Z. Andreas Osiander: prefácio ao De revolutionibus orbium coelestium de Copérnico. Cadernos de História e Filosofia da Ciência, 1, p. 44-61, 1980.

Масн, E. The science of mechanics. La Salle, Illinois: The Open Court, 1974.

Mandelbaum, M. Philosophy, science and sense perception. Baltimore: Johns Hopkins University Press, 1964.

MaDonald, J. F. Properties and causes: an approach to the problem of hypothesis in the scientific methodology of Sir Isaac Newton. Annals of Science, 28, 3, p. 217-33, 1972.

MoraEs, J. Q. K. (Org.). Materialismo e evolucionismo. Campinas: CLE, 2007. (Coleção CLE, v. 47.).

Newton, I. Mathematical principles of natural philosophy. Tradução A. Motte; revisão F. Cajori. Berkeley/ Los Angeles: University of California Press, 1934. (Principia)

. Opticks, or a Treatise of the reflections, refractions, infractions, and colours of Light. 4 ed. London: William Innys, 173o. (Óptica)

Popper, K. Conjectures and refutations. London: Routledge and Kegan, 1972.

TEGG, T. et al. (Ed.). The works of John Locke. Dublin: Cumming, 1823. $10 \mathrm{v}$.

Tipton, I. C. (Ed.). Locke on human understanding. Selected Essays. Oxford: Oxford University Press, 1977.

Shapiro, A. E. Newton's “experimental philosophy”. Early Science and Medicine, 9, 3, p. 185-217, 2004.

Yolton, J. W. John Locke and the compass of human understanding. Cambridge: Cambridge University Press, 1970 .

Yost Junion, R. M. Locke's rejection of hypotheses about sub-microscopic events. Journal of the History of Ideas, 12, p. 111-3o, $195^{1}$.

Wilson, M. D. Supperadded properties: the limits of mechanism in Locke. American Philosophical Quarterly, 16, 2, p. 14,3-50, 1979.

Winkler, K. (Ed.). The Cambridge companion to Berkeley. Cambridge: Cambridge University Press, 2005. 